\title{
Growth, mortality, and reproduction of Tagelus plebeius (Bivalvia: Solecurtidae) in Southeast Brazil
}

\author{
Camila Fernanda da Silva • Guilherme Nascimento Corte $\cdot$ Leonardo Querobim Yokoyama • \\ Jolnnye Rodrigues Abrahão • Antônia Cecília Zacagnini Amaral
}

Received: 25 March 2014/Revised: 12 September 2014/ Accepted: 14 October 2014/Published online: 28 October 2014

(c) Springer-Verlag Berlin Heidelberg and AWI 2014

\begin{abstract}
Tagelus plebeius (Lightfoot, 1786) is a stout razor clam that is economically exploited in several countries, including several local fisheries along the Brazilian coast. Despite its wide distribution and economic importance, there are few studies that have examined the population biology of this species. This study aimed to improve the current knowledge about the biology of $T$. plebeius by investigating its growth and mortality on a subtropical sandy beach in Southeast Brazil over a 1-year
\end{abstract}

Communicated by H.-D. Franke.

C. F. da Silva $(\bowtie) \cdot$ G. N. Corte

Programa de Pós-Graduação em Ecologia, Laboratório de Bentos Marinho, Departamento de Biologia Animal, Instituto de Biologia, Universidade Estadual de Campinas (UNICAMP), Rua Monteiro Lobato, 255, Campinas, SP CEP 13083-862, Brazil

e-mail: fercamis@gmail.com

G. N. Corte

e-mail: guilhermecorte@yahoo.com.br

L. Q. Yokoyama · J. R. Abrahão · A. C. Z. Amaral Laboratório de Bentos Marinho, Departamento de Biologia Animal, Instituto de Biologia, Universidade Estadual de Campinas (UNICAMP), Rua Monteiro Lobato, 255, Campinas, SP CEP 13083-862, Brazil

e-mail: lqyokoyama@gmail.com

J. R. Abrahão

e-mail: jolnnye@yahoo.com.br

A. C. Z. Amaral

e-mail: ceamaral@unicamp.br

Present Address:

L. Q. Yokoyama

Departamento de Ciências do Mar, Universidade Federal de São Paulo (UNIFESP), Campus Baixada Santista, Avenida Almirante Saldanha da Gama, 89, Santos, SP CEP 11030-040, Brazil period. In addition, the reproduction of $T$. plebeius was analyzed through qualitative and quantitative histological analyses during the last 7 months of the study. The parameters of the von Bertalanffy growth function were estimated to be $L_{\infty}=74.14 \mathrm{~mm}, K=0.52$ year $^{-1}$, $C=0.47$, and $\mathrm{WP}=0.94$. The instantaneous mortality rate $(Z)$ was 2.16 year $^{-1}$, and the life span was 2.58 years. We confirmed variations $(H=651.35 ; P<0.05)$ in the shell length over the months of the study, and the recruitment was higher-but still low-in summer. Four cohorts were observed in the distribution of shell length frequencies. The sex ratio of the population was 1:1 during the study period, and a synchronism in gonadal development and spawning was found between males and females. The high mortality $(Z)$ and low recruitment rates can be interpreted as reflecting that the population of T. plebeius is under a low restoration process and could be an indication that this species has an endangered status in the study area.

Keywords Population dynamics - Reproductive analysis $\cdot$ Stout razor clam $\cdot$ Subtropical sandy beach

\section{Introduction}

Artisanal marine invertebrate fisheries on sandy shores have critical socioeconomic and ecological implications, mainly in developing countries. These small-scale fisheries represent a source of food for subsistence, generate important direct income to the community of fishermen, and in some cases, provide high revenues to the country (Defeo 2003). Nonetheless, they may also represent a source of impact on exploited species, reducing-or even depleting - species density and biomass (Ferns et al. 2000; Fagundes et al. 2004) and strongly affecting their 
functional roles in marine ecosystems (Dayton et al. 1995; Gutiérrez et al. 2004; Anderson et al. 2011).

Since 1950, global invertebrate catch numbers have increased sixfold (Anderson et al. 2011), yet this exponential growth was not supported by management or regulations based on solid scientific knowledge (Defeo 2003). Population studies, which provide information about distribution, abundance, growth, and reproduction, are essential to achieve sustainable development of fisheries and to secure the long-term use of these resources (Metaxatos 2004; Calderon-Aguilera et al. 2010). However, exploited species are rarely monitored in independent research surveys to assess population trends (Anderson et al. 2011).

The suspension-feeding stout razor clam Tagelus plebeius is distributed along the coast of the Americas, from North Carolina ( $\left.34^{\circ} \mathrm{N}, \mathrm{USA}\right)$ to the San Matias Gulf $\left(41^{\circ} \mathrm{S}\right.$, Argentina) (Rios 1994). This species is commonly used as a fishery resource in the majority of its occurrence area (Chile, Argentina, and Brazil); recently, an increasing commercialization of this species has been recorded (Gutiérrez et al. 2004). Despite its wide distribution and economic importance, there is a great lack of knowledge about the population biology of T. plebeius. To date, the population studies focusing on this species have been restricted to those conducted by Holland and Dean (1977a, b) in the USA, by Clédon et al. (2004) in Argentina, and by Viégas (1982), Abrahão and Amaral (1999), Abrahão et al. (2010), and Ceuta and Boehs (2012) in Brazil.

The increasing exploitation of T. plebeius, together with the low number of studies of its biology, is expected to result in negative impacts on these populations (Gutiérrez et al. 2004; Beasley et al. 2005). Aiming to enhance the knowledge about $T$. plebeius, we analyzed its population biology over the course of 1 year on a subtropical sandy beach in Southeast Brazil. During the last 7 months of the study, we combined population dynamics analysis with reproductive analysis, an approach that was performed for the first time for this species.

\section{Materials and methods}

Study area

This study was conducted at Camaroeiro Beach $\left(23^{\circ} \mathrm{S}\right.$, $45^{\circ} \mathrm{W}$ ), an intermediate beach (Farinaccio and Tessler 2006; Amaral and Denadai 2011) located on the northern portion of Caraguatatuba Bay, State of São Paulo, Brazil (Fig. 1). Camaroeiro Beach is approximately $300 \mathrm{~m}$ long and $50 \mathrm{~m}$ wide and is composed of moderate to poorly sorted fine sand, with intermediate calcareous content
Fig. 1 Map of the location of Camaroeiro Beach on the northern portion of Caraguatatuba Bay, State of São Paulo, Brazil

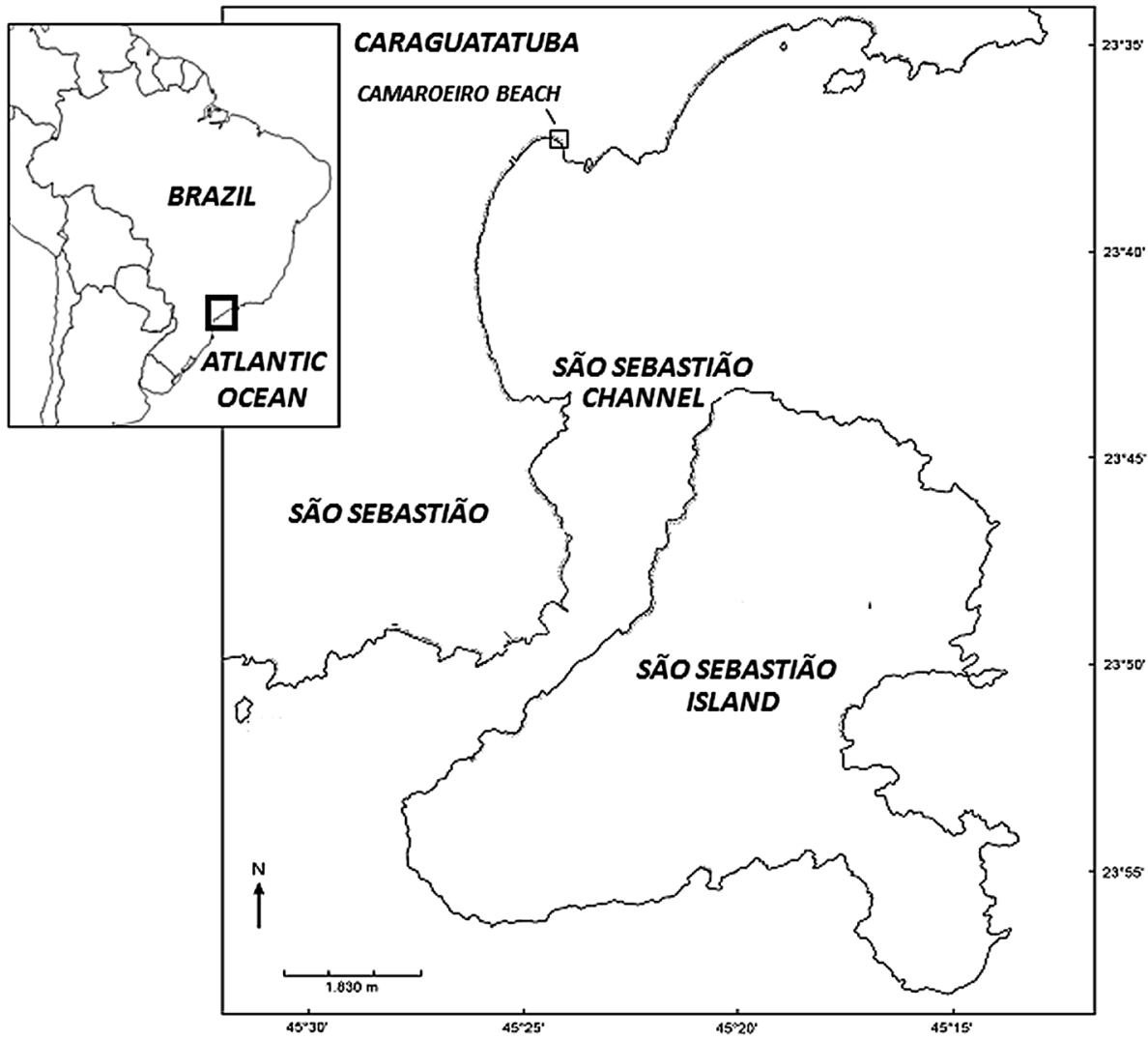


(1.51-6.04\%) and low organic matter content (0.28-0.99 \%) (Amaral and Denadai 2011).

\section{Sampling procedures}

Sampling was performed at spring low tide at monthly intervals from March 2006 through February 2007. Once the individuals bury themselves deeply in the sediment $(50 \mathrm{~cm})$, a great effort is involved in sampling, frequently precluding population studies. To achieve the minimum number of individuals necessary for analysis, we chose to apply a standard procedure used to sample razor clams (Gutiérrez and Iribarne 2003; Vásquez et al. 2006; Abrahão et al. 2010; Ceuta and Boehs 2012; Farias and Rocha-Barreira 2012) instead of using the most common methods used in macrofaunal studies (e.g., transects and/or random stratification). This approach consisted of (1) identifying the area of greatest abundance of $T$. plebeius (the upper level of the intertidal region of Camaroeiro Beach); (2) establishing a sector in this area (a $450 \mathrm{~m}^{2}$ sector-30 $\mathrm{m}$ long and $15 \mathrm{~m}$ wide); and (3) excavating the sand in all locations where $T$. plebeius marks could be observed inside the sector. By following this procedure, approximately thirty replicates were collected in each month, which allowed us to achieve the minimum number of individuals necessary to perform growth and mortality analyses. However, the lack of randomization prevented us from performing abundance tests. In addition to biological sample collection, the salinity of the interstitial water was measured in situ with a Goldberg T/C portable refractometer (Mod. $\left.10419^{\circledR}\right)$, and daily sea temperature data were obtained from the Marine Biology Center of the University of São Paulo (CEBIMar), which is located $40 \mathrm{~km}$ from Camaroeiro Beach.

Population dynamics analysis

The shell length of all sampled $T$. plebeius individuals was measured with a digital caliper to the nearest $0.01 \mathrm{~mm}$ and used in the growth analysis. The data were modeled using the von Bertalanffy growth function modified for seasonality (VBGF: García-Berthou et al. 2012):

$L_{t}=L_{\infty}\left[1-e^{\left[-K\left(t-t_{0}\right)-(K C / 2 \pi) \sin 2 \pi\left(t-t_{\mathrm{s}}\right)+(K C / 2 \pi) \sin 2 \pi\left(t_{0}-t_{\mathrm{s}}\right)\right]}\right]$

where $L_{t}$ is the shell length $(\mathrm{mm})$ at time $t ; L_{\infty}$ is the theoretical maximum shell length $(\mathrm{mm})$ attained by the species; $K$ (year ${ }^{-1}$ ) is the curvature parameter; $C$ is a constant for the amplitude of the seasonal growth oscillation; $t_{0}$ is the age at length zero; and $t_{\mathrm{s}}$ is the initial point of seasonal oscillation in relation with $t_{0}$ (Gayanilo and Sparre
2005). The winter point (WP), i.e., the period of growth reduction, expressed as a decimal fraction of the year, was obtained through the equation $\mathrm{WP}=t_{\mathrm{s}}+0.5$ (Gayanilo and Sparre 2005).

Two different methods were used to calculate the VBG parameters:

1. Modal progression analysis (MPA) [the NORMSEP routine of the FISAT II statistical program (Gayanilo and Sparre 2005)], which consists of (a) separate shell length-frequency distributions using the NORMSEP routine; (b) assignment of absolute ages for the respective cohorts (lengths) and generation of the age-length relationship; and (c) the use of the agelength results to fit the von Bertalanffy growth curve modified for seasonal oscillation in growth by nonlinear least squares (Gómez and Defeo 1999; Defeo et al. 2001).

2. Length-frequency distribution analysis (LFDA), which was performed using the electronic length frequency analysis (ELEFAN I) routine of the FISAT II program. This routine generates a growth curve from the "best fit" to the length-frequency data and calculates the VBGF parameters. The different subroutines of ELEFAN (K-scan, response surface analysis, and automatic search) were used to identify the VBGF that best fit the monthly length-frequency data using the $R n$ value as a criterion of fit (Petracco et al. 2003; Defeo and Martínez 2003; Herrmann et al. 2009).

The results from both methods were compared and evaluated, and the shell growth and mortality rates were modeled using the most appropriate parameters (Chatzinikolaou and Richardson 2008).

The growth index phi prime $\phi^{\prime}=2 \log _{10}\left(L_{\infty}\right)+$ $\log _{10} K$ (Pauly and Munro 1984; Defeo et al. 1992) was employed as a measure of overall growth performance.

The theoretical life span $\left(t_{\max }\right)$ was estimated based on the inverse of the von Bertalanffy growth equation, considering the maximum shell length as $95 \%$ of the asymptotic length (Herrmann et al. 2011):

$t_{\max }=\frac{\left[\ln L_{95 \%}-\ln \left(L_{\infty}-L_{95 \%}\right)\right]}{K}$

The total mortality rate $Z$ was estimated from the overall size-frequency distribution and the VBGF parameters based on a size-converted catch curve (Pauly 1984a, b; Lomovasky et al. 2002):

$\frac{N_{i}}{\Delta t_{i}}=N_{0} e^{-Z t_{i}}$

where $N_{i}$ is the number of individuals in size class $i, \Delta t_{i}$ is the time required to grow through this size class, and $t_{i}$ is 
the relative age in the midsize of class $i$. Total mortality $Z$ is computed using the linear regression:

$\operatorname{Ln}\left(\frac{N_{i}}{\Delta t_{i}}\right)=a+b t_{i} ; \quad Z=-b$

The relative level of predation pressure was determined according to Brey and Gage (1997) and Lomovasky et al. (2002) from the relationship between the mortality rate $Z$ and growth constant $K$ using the index:

$\Delta_{Z / K}=\log \left(\frac{Z_{\text {measured }}}{Z_{\text {predicted }}}\right) ; \quad-\infty \leq \Delta_{Z / K} \leq+\infty$

Negative values indicate exploitation below the empirically determined average level and positive values above the empirically determined average level in benthic populations. $Z_{\text {predicted }}$ is derived from the empirical relation:

$\log \left(Z_{\text {predicted }}\right)=0.339+1.037 \times \log (K)$

Temporal variations in mean size were assessed with a nonparametric Kruskal-Wallis test because the Kolmogorov-Smirnov test showed that the data were not normally distributed.

\section{Reproductive biology analysis}

From November 2006 through May 2007, the twenty largest individuals (all larger than $40 \mathrm{~mm}$ in shell length) were selected for reproductive analysis. Their soft parts were removed from the shell, fixed in Bouin's fluid for $24 \mathrm{~h}$, and then preserved in $70 \%$ ethanol. A cross-sectional block containing the gonad was dissected from each clam, dehydrated in an ethanol gradient (80, 95, and $100 \%)$, cleared in xylene, and embedded in paraffin. Sections (5-7 $\mu \mathrm{m}$ thick) were stained in Harris's hematoxylin and counter-stained in eosin (Humanson 1979). The slides were examined under $80 \times, 160 \times$, and $320 \times$ magnifications to determine the sex and stage of reproductive development. The gametogenic stages were defined according to the predominance of specific cells (males: spermatogonia, spermatocytes, spermatids, and spermatozoids; females: oogonia, pre-vitellogenic oocytes, vitellogenic oocytes, and mature oocytes), a strategy modified from Gaspar and Monteiro (1998) and Morsan and Kroeck (2005). For each female, the diameter of the first 40 oocytes with an evident nucleus and nucleolus was measured to verify differences in the mean oocyte area during the study period. The oocyte diameter $(d)$ was considered as the mean of four different measurements passing through the center of each oocyte (Corte et al. 2013), and the area of each oocyte was calculated as a circle $\left(\pi(d / 2)^{2}\right)$. A Kruskal-Wallis test was applied to assess whether the average oocyte areas were different among months.

\section{Results}

Abiotic parameters

The interstitial salinity ranged from 16.6 in January 2007 to 28.6 in November 2006, and the sea water temperature ranged between $22.17{ }^{\circ} \mathrm{C}( \pm 0.88)$ in September 2006 and $26.18{ }^{\circ} \mathrm{C}( \pm 0.82)$ in March 2006.

Population dynamics

The mean shell length of T. plebeius at Camaroeiro Beach during the study period was $47.2 \mathrm{~mm}( \pm 10.79 \mathrm{~mm})$ and varied throughout the months $(H=651.357 ; P<0.05)$,

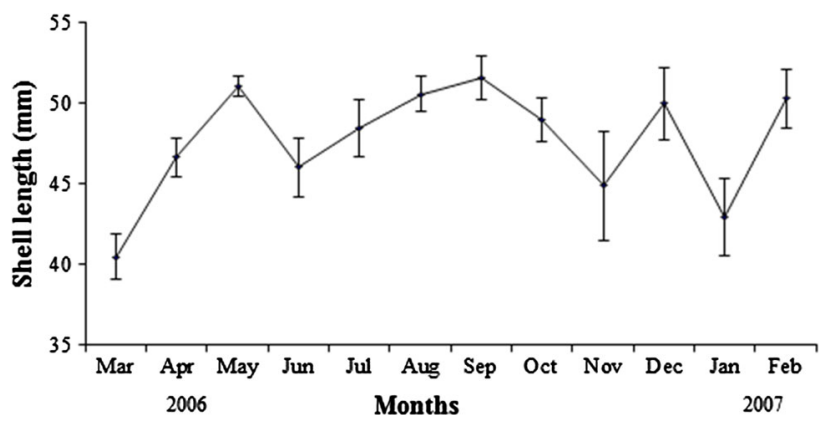

Fig. 2 Variation in the mean shell length $(\mathrm{mm})$ from March 2006 to February 2007. Bars above and under each dark quadrate indicate the standard error of the mean

Table 1 Growth parameters estimated by NORMSEP plus nonlinear least squares fit of the von Bertalanffy function, and by ELEFAN routine

\begin{tabular}{|c|c|c|c|c|}
\hline \multicolumn{3}{|l|}{ MPA } & \multicolumn{2}{|l|}{ LFDA } \\
\hline \multicolumn{3}{|l|}{ NORMSEP } & \multicolumn{2}{|l|}{ ELEFAN } \\
\hline Parameter & Mean $( \pm \mathrm{SD})$ & $P$ & Parameter & \\
\hline$L_{\infty}(\mathrm{mm})$ & $74.14(4.01)$ & $<0.001$ & $L_{\infty}(\mathrm{mm})$ & 74.6 \\
\hline$K\left(\right.$ year $\left.^{-1}\right)$ & $0.52(0.05)$ & $<0.001$ & $K\left(\right.$ year $\left.^{-1}\right)$ & 0.4 \\
\hline$C$ & $0.47(0.15)$ & 0.003 & $C$ & 0.4 \\
\hline WP & $0.94(0.09)$ & $<0.001$ & WP & 0.8 \\
\hline$r$ & 0.99 & & $R n$ & 0.298 \\
\hline$\phi^{\prime}$ & 3.46 & & $\phi^{\prime}$ & 3.35 \\
\hline$t_{\max }($ year $)$ & 2.58 & & $t_{\max }($ year $)$ & 3.28 \\
\hline$Z$ (year) & 2.16 & & $Z$ (year) & 1.85 \\
\hline$\Delta_{Z / K}$ & 0.29 & & $\Delta_{Z / K}$ & 0.34 \\
\hline Smallest (mm) & 4.98 & & & \\
\hline Largest (mm) & 65.14 & & & \\
\hline
\end{tabular}

$L_{\infty}$ asymptotic length, $K$ curvature parameter, $C$ constant for the amplitude of seasonal oscillation of growth, $W P$ point of lowest growth rate in the year, $r$ correlation coefficient, $\phi^{\prime}$ standard growth index (Pauly and Munro 1984), $t_{\max }$ life span, $Z$ mortality rate, $\Delta_{Z / K}$ predation pressure, $S D$ standard deviation 


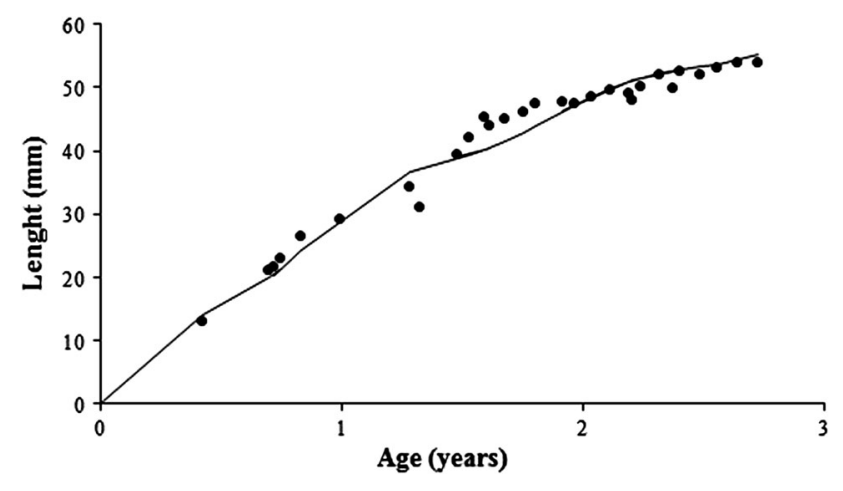

Fig. 3 Average growth estimated for the population. The dots represent the mean size of each cohort at the specific relative age (year). The line represents the expected growth according to the seasonal version of the VBG equation observed for the population lower mean in March 2006 (40.44 \pm 9.71) (Fig. 2). The smallest individual $(4.98 \mathrm{~mm})$ was recorded in December 2006 and the largest $(65.14 \mathrm{~mm})$ in January 2007.

Similar growth parameters for the population of $T$. plebeius at Camaroeiro Beach were recorded when using MPA and LFDA methods (Table 1), which strengthens our findings and demonstrates the accuracy of our growth estimates. However, according to Chatzinikolaou and Richardson (2008), the MPA is a more appropriate method for analyzing data from relatively non-mobile populations due to large variations in annual recruitment. Therefore, we used the MPA results to discuss the $T$. plebeius population dynamics at Camaroeiro Beach.

The asymptotic size $\left(L_{\infty}\right)$ estimated by MPA was approximately $74 \mathrm{~mm}$, with a moderate growth rate
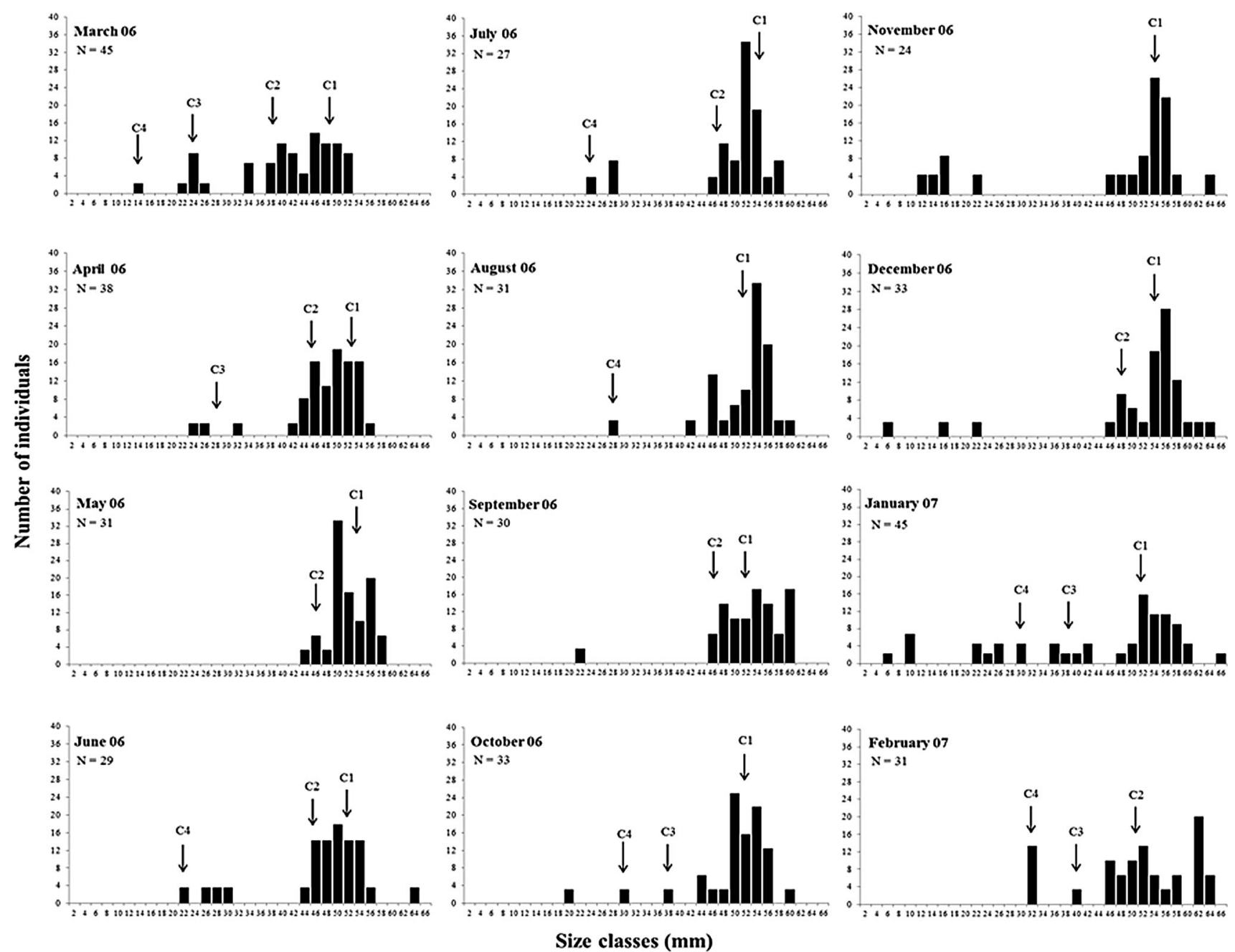

Fig. 4 Relative frequency $(\%)$ of shell length classes $(\mathrm{mm})$ and population cohort distribution $(C 1, C 2, C 3$, and $C 4)$ from March 2006 to February 2007

with a higher mean in May $2006(51.03 \pm 3.54)$ and a $\quad\left(K=0.5\right.$ year $\left.^{-1}\right)$. The individuals grew relatively rapidly 
in their first years, and parameter $C$ (degree of seasonal variation) indicated a moderate oscillation in growth (Fig. 3). The value of WP (the point of lowest growth rate during the year, $\left.\mathrm{WP}=t_{\mathrm{s}}+0.5\right)$ showed growth reduction at the end of the year. The positive values of the $\Delta_{Z / K}$ parameter indicated exploitation above the empirically determined average level of $T$. plebeius. Four cohorts were observed and tracked during the study period $(\mathrm{C} 1, \mathrm{C} 2, \mathrm{C} 3$, and C4) (Fig. 4).

\section{Reproductive biology}

A total of 131 individuals were analyzed, and the sex ratio of the population was $1: 1\left(\chi^{2}=0.37 ; P=0.54\right)$. No hermaphrodite individuals or sex reversals were observed during the study period.

After the histological analysis, five gametogenic stages were established for females (early active gametogenesis, late active gametogenesis, ripe, spawning, and spent) and three for males (gametogenesis, ripe, and spawning) (Table 2; Figs. 5, 6).

Females in the early active gametogenesis stage were observed in small percentages in November 2006 and mainly in February and March 2007 (Fig. 7a). The late active gametogenesis stage was identified in November 2006 and March and April 2007, with a peak in the latter month. Females in the ripe stage were observed in late spring and summer (November 2006-February 2007) and in autumn (May 2007). Individuals in the spawning stage were observed in the same period as the ripe stage, from November 2006 to February 2007, with a peak in December 2006 and January 2007 and another in May 2007. Females in the spent stage were observed in small percentages from January to April 2007, after the spawning peak in summer.

Males in the gametogenesis stage were observed at almost all times throughout the study period, with a peak in February and March 2007 (Fig. 7b). The ripe stage was observed in late spring and summer, from November 2006 to January 2007, and in autumn, from April to May 2007. Individuals in the spawning stage were observed from November 2006 to January 2007 and also in May 2007. The gametogenic stages of the males and females were synchronized over the period of study.

The quantitative histological analyses corroborate the qualitative findings, and lower values of the mean oocyte area were recorded from February to May 2007 ( $H=96.66 ; P<0.001)$, when a higher number of females in gametogenesis was observed (Fig. 8).

\section{Discussion}

The VBG parameters estimated for the $T$. plebeius population from Camaroeiro Beach were higher or intermediate when compared to the results from previous studies. The growth curve constructed using MPA predicted an asymptotic size $\left(L_{\infty}\right)$ of $74.14 \mathrm{~mm}$ and a growth rate $(K)$ of 0.52 year $^{-1}$. This asymptotic size is larger than the

Table 2 Description of the gametogenic stages of females and males

\begin{tabular}{|c|c|c|}
\hline Stage & Brief description of gonad & Figures \\
\hline \multicolumn{3}{|l|}{ Female } \\
\hline Early gametogenesis & $\begin{array}{l}\text { The connective tissue is abundant, the size of the follicles is small, and the initial stage } \\
\text { of gametogenesis is present. Oocytes lie at the periphery of the gonadal walls and are } \\
\text { attached to the basal membrane by a stalk }\end{array}$ & $5 \mathrm{a}$ \\
\hline Late gametogenesis & $\begin{array}{l}\text { The size of the follicles increased and the initial stage of gametogenesis is still present, } \\
\text { but restricted to the periphery of the follicles. Most mature oocytes are free in the } \\
\text { lumina while some are still attached to the basal membrane by a thin stalk }\end{array}$ & $5 b$ \\
\hline Ripe & $\begin{array}{l}\text { The connective tissue has been reduced by the enlargement of the follicles by ripe } \\
\text { gametes. The mature oocytes take polygonal shape due to packing. A decrease in the } \\
\text { percentage of oogonia and pre-vitellogenic oocytes attached to the wall was also seen }\end{array}$ & $5 \mathrm{c}$ \\
\hline Spawning & Gametes are being released and empty spaces were observed in the follicular lumina & $5 d$ \\
\hline Spent & The follicle lies empty with occasional residual oocytes present & $5 e$ \\
\hline \multicolumn{3}{|l|}{ Male } \\
\hline Gametogenesis & $\begin{array}{l}\text { The connective tissue is abundant, and the size of the follicles is small. Spermatocytes } \\
\text { proliferate toward the lumina, and rows of germinal cells in phases of maturation } \\
\text { (spermatogonias, spermatocytes, and spermatids) form a germinal layer near the } \\
\text { gonadal wall }\end{array}$ & $6 \mathrm{a}$ \\
\hline Ripe & $\begin{array}{l}\text { The connective tissue has been reduced by the enlargement of the follicles by ripe } \\
\text { gametes. Lumina is packed with ripe spermatozoa. }\end{array}$ & $6 \mathrm{~b}$ \\
\hline Spawning & Follicles showed a radial arrangement of the spermatozoa as they are being released & $6 \mathrm{c}$ \\
\hline
\end{tabular}



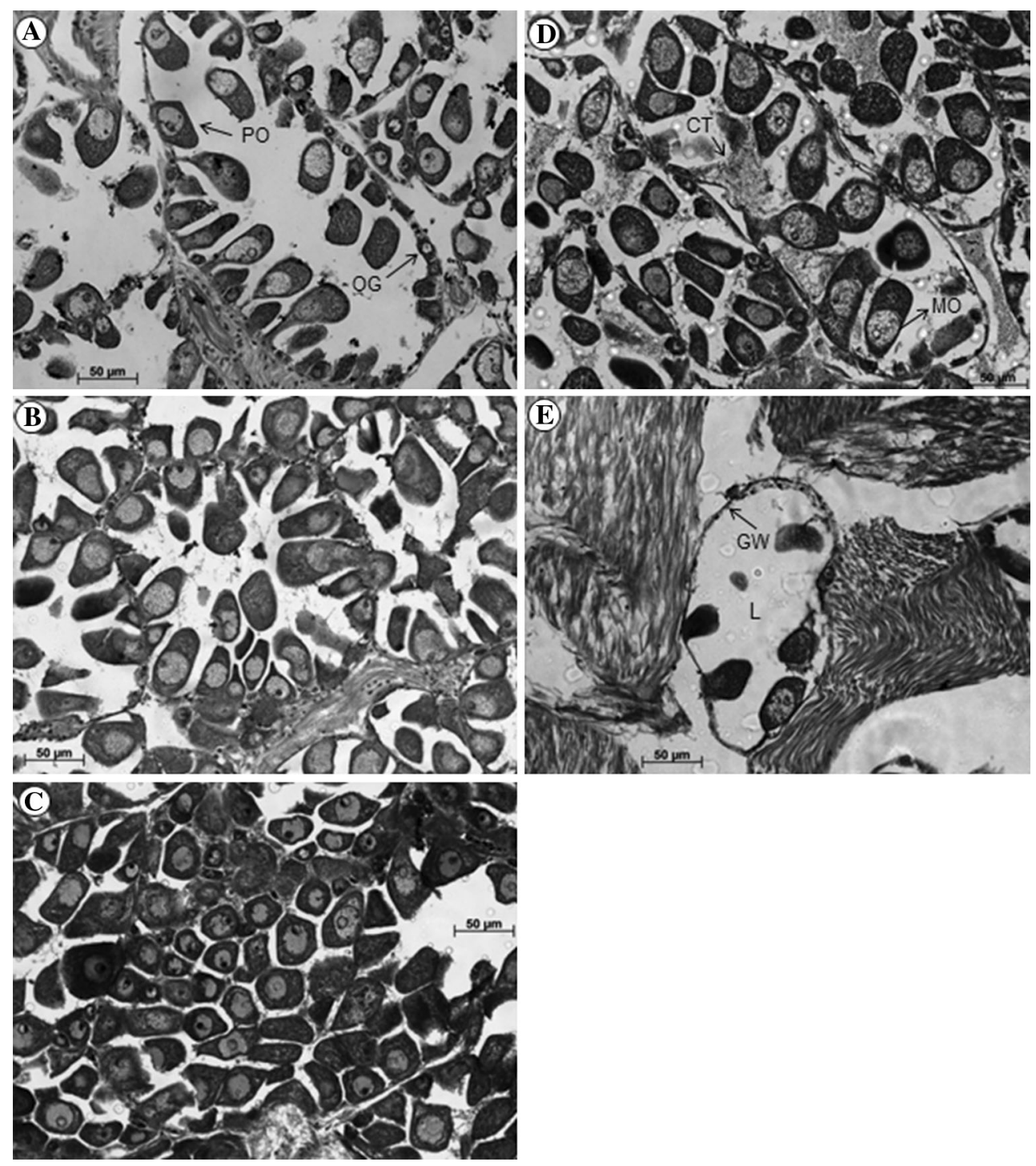

Fig. 5 Female gonads in different stages of maturation. a Early gametogenesis, b late gametogenesis, $\mathbf{c}$ ripe, $\mathbf{d}$ spawning, e spent. $C T$ connective tissue, $G W$ gonadal wall, $M O$ mature oocyte, $L$ lumina, $O G$ oogonia, $P O$, pre-vitellogenic oocyte

values estimated by Holland and Dean (1977b: $65 \mathrm{~mm}$ at $33^{\circ} \mathrm{S}$ ), Viégas (1982: $51.73 \mathrm{~mm}$ at $\left.9^{\circ} \mathrm{S}\right)$, and Abrahão et al. (2010: $67.01 \mathrm{~mm}$ at $23^{\circ} \mathrm{S}$ ) but is lower than the maximum length recorded for the species $(90 \mathrm{~mm}$ : Holland and Dean 1977a, b) (Table 3). The value of $K\left(0.52\right.$ year $\left.^{-1}\right)$ was intermediate compared with those estimated by Abrahão et al. (2010: 1.73 year $^{-1}$ ) and Viégas (1982: 0.25 and 0.08 year $^{-1}$ ) for T. plebeius and by Urban (1996: 0.232 year $^{-1}$ at $36^{\circ} \mathrm{S}$ ) for Tagelus dombeii (Lamarck, 1818) (Table 3). The growth index (the overall measure of growth performance) of $T$. plebeius at Camaroeiro Beach (3.46) was also intermediate when compared to the value of 3.89 estimated by Abrahão et al. (2010) and 3.26 estimated for T. dombeii (Urban 1996) (Table 3).
Several studies have related differences in growth parameters of sandy beach species to environmental characteristics such as temperature (Defeo and Cardoso 2002) and sediment features (Henderson and Richardson 1994; Grant and Daborn 1994; Lomovasky et al. 2006). According to the latitudinal gradient hypothesis (LGH) an extension of Bergmann's rule proposed by Defeo and Cardoso (2002) - there is a positive relationship between body size and latitude, and species inhabiting tropical and subtropical zones would present a higher growth rate and lower asymptotic size than temperate species due to the increase in metabolic rate at higher temperatures. Despite the widely accepted influence of temperature on growth of marine bivalves, our results differed from those recorded by Abrahão et al. (2010), which analyzed the growth 

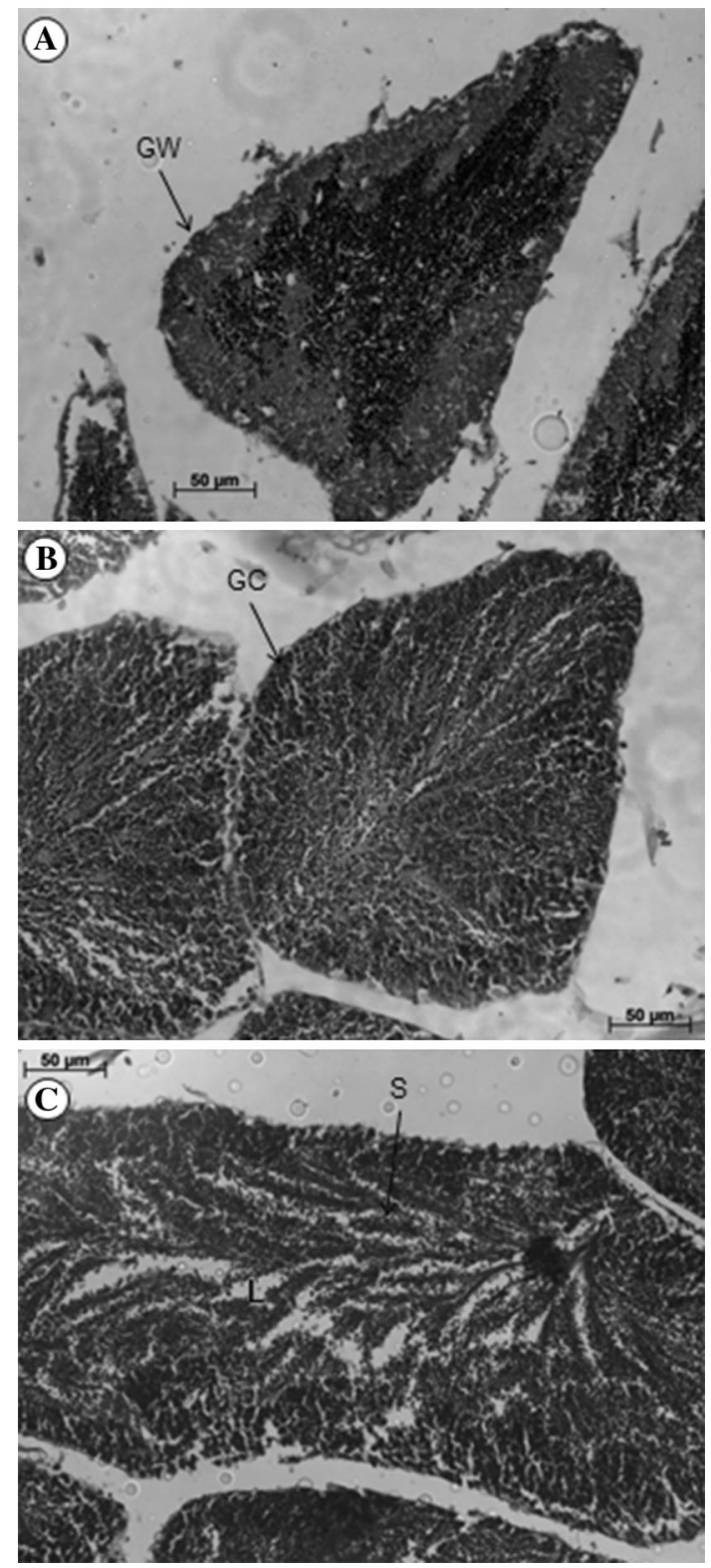

Fig. 6 Male gonads in different stages of maturation. a Gametogenesis, b ripe, c Spawning. $G W$ gonadal wall, $G C$ germinal cells, $L$ lumin, $S$ spermatozoa

patterns of T. plebeius in an area at the same latitude with similar temperatures. In this sense, it is possible that other environmental factors may override the influence of temperature on the growth rate and asymptotic size of $T$. plebeius.

The salinity fluctuations observed in the study area represent another factor that does not appear to strongly affect the population biology of T. plebeius at Camaroeiro Beach. The range of interstitial salinity recorded for Camaroeiro Beach (16.6-28.6) is lower than that registered by Abrahão and Amaral (1999) (12-30) at Enseada Beach (Southeast Brazil) and by Farias and Rocha-Barreira (2012)
(5-40) in the Ceará River estuary (Northeast Brazil), who observed no influence of salinity on the population parameters of $T$. plebeius. These results confirm the euryhalinity of $T$. plebeius and suggest that this factor does not exert a major control over the population biology of this species in most of its occurrence area.

Fine sediments and high organic matter content are commonly viewed as indications of higher environmental stability and food availability, conditions that may enhance the growth and body size of suspension-feeding clams (Bayne and Worrall 1980; Grant and Daborn 1994). Comparing the results observed at Camaroeiro Beach with those of Abrahão et al. (2010), the growth index (the overall measure of growth) was higher in the latter study area, which presented finer sand and a higher organic matter content. Although not conclusive, these results may reinforce the influence of sediment characteristics and organic matter content on T. plebeius growth.

The smallest $T$. plebeius registered at Camaroeiro was $4.98 \mathrm{~mm}$, suggesting that individuals smaller than this length either were not present in the population or were not collected. Although our sampling design may have a degree of size selectivity (larger individuals produce larger marks and could be more easily captured), we strongly attempted to avoid sampling bias by searching for all marks, and both small and large animals were collected at all times of the year. As observed in the present study, Holland and Dean (1977a) and Abrahão et al. (2010) also recorded few juveniles in their study areas. This low number of small individuals may be caused by (1) separate nursery sites for settlement; from these nursery habitats, juveniles then migrate and recruit into the main population sites and/or (2) a higher selective pressure on the juveniles. To test the first hypothesis, we sampled different areas in the intertidal and subtidal zones of Camaroeiro Beach and did not find a nursery site. However, more sampling is needed to proper test this hypothesis.

A higher selective pressure on juveniles may explain (at least in part) the low number of those individuals in $T$. plebeius populations. According to Verween et al. (2007), this stage of the invertebrate life history pattern is the most sensitive to abiotic parameters and age-specific predation pressure by birds, gastropods, and fishes. Larger bivalves tend to bury deeper, reducing their risk of predation, whereas young individuals remain near the surface of the substrate due to their short siphons (Hines et al. 1990; Lin and Hines 1994). This behavior results in a higher predation risk and increased rates of natural mortality over smaller individuals, as observed for T. plebeius in South Carolina, USA (Holland and Dean 1977b) and T. dombeii in Chile (Lardies et al. 2001).

The population of T. plebeius at Camaroeiro Beach was composed of four cohorts that were tracked during the entire study period. Similarly, Abrahão et al. (2010) found 
Fig. 7 Relative frequency (\%) of the gametogenic stages in each month for both females (a) and males (b) from November 2006 to May 2007

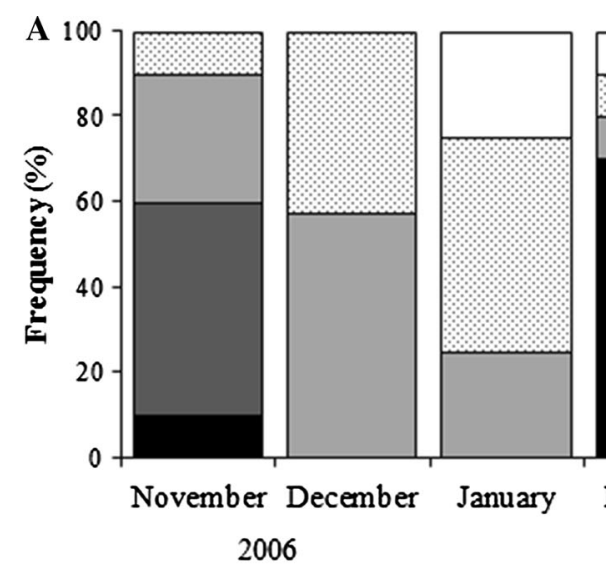

Early active gametogenesis $\square$ Ripe $\square$ Spent

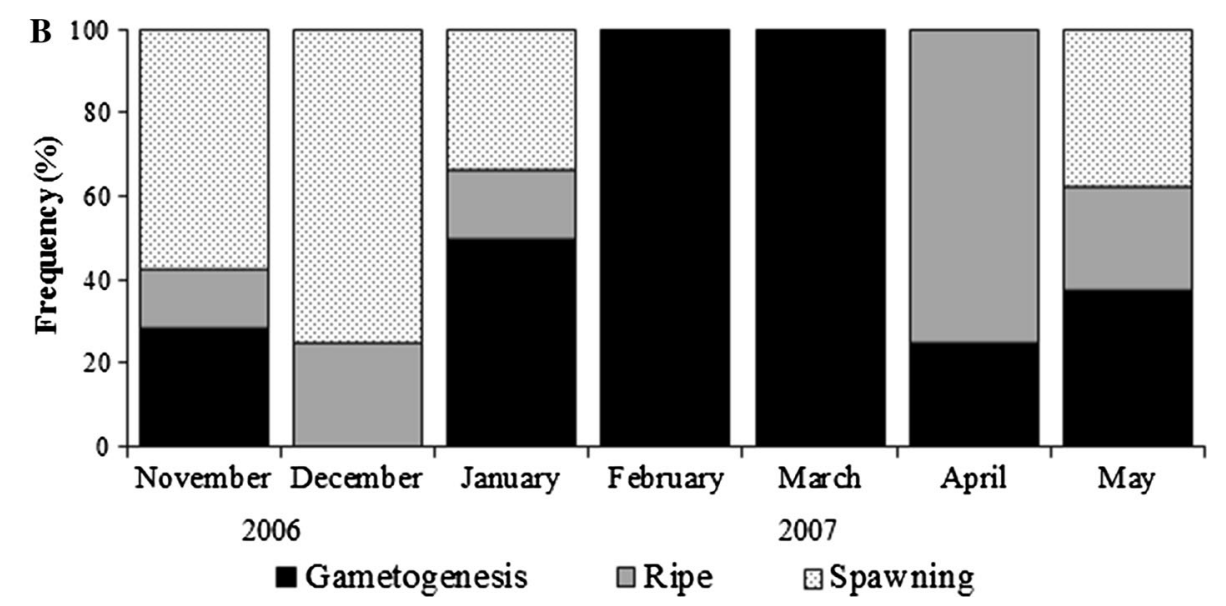

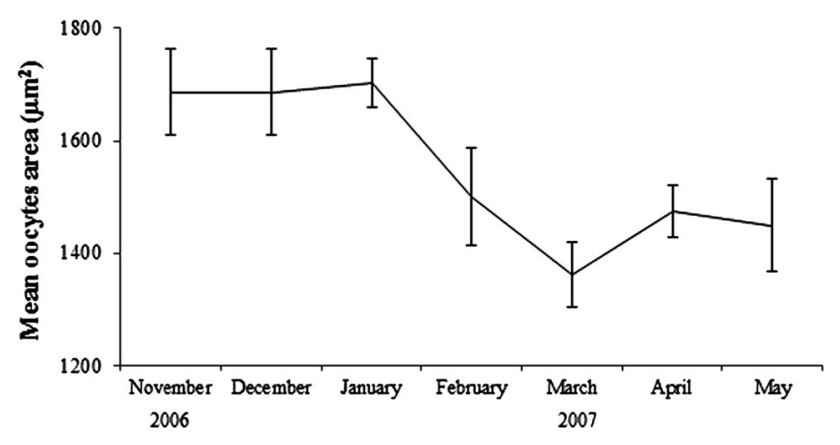

Fig. 8 Variation in the mean oocytes area $\left(\mu \mathrm{m}^{2}\right)$ from November 2006 to May 2007

three cohorts in Southeast Brazil. The occurrence of several different generations occurring at the same time is most likely due to the short life span of the species in the study area (approximately 2.58 years). An even shorter life span for T. plebeius was observed by Abrahão et al. (2010)populations ranging from 1.58 to 2.25 years (Table 3 ); however, other studies suggest a long-lived pattern for razor clams. A life span of 19 years was reported for Ensis siliqua (Linnaeus, 1758) in Ireland (Fahy and Gafnney 2001), and Barón et al. (2004) suggested a 14-16 year age for E. macha (Molina, 1782) in Argentina, as based on the growth marks in its shell. The low longevities registered for T. plebeius along the Brazilian coast may be related to interspecific differences but also to a high mortality rate at lower latitudes, which could be explained by a combination of increasing metabolism at higher temperatures and insufficient food availability (Defeo and Cardoso 2004). Strengthening this hypothesis, the mortality rate observed for T. plebeius at Camaroeiro Beach $\left(2.16\right.$ year $\left.^{-1}\right)$ is slightly lower than that reported by Abrahão et al. (2010: 3.12) at a similar latitude (Table 3), but is much higher than the values reported for other bivalves inhabiting colder areas, such as Protothaca thaca (Molina, 1782) (0.47 year $^{-1}$ at $36^{\circ} \mathrm{S}$, Urban and Campos 1994), Callista chione (Linnaeus, 1758) (0.27 year ${ }^{-1}$ at $38^{\circ} \mathrm{S}$, Metaxatos 2004), and Eurhomalea exalbida (Dillwyn, 1817) 
Table 3 Latitudinal variation in growth parameters and reproductive events of T. plebeius and T. dombeii

\begin{tabular}{llllllllll}
\hline Species & $L_{\infty}(\mathrm{mm})$ & $\left.K\left(\mathrm{year}^{-1}\right)\right)$ & $Z\left(\mathrm{year}^{-1}\right)$ & Life span (year) & $\phi^{\prime}$ & Recruitment & Spawning & Lat. & Source \\
\hline T. plebeius & 65 & - & - & - & - & - & - & $33^{\circ} 20^{\prime}$ & Holland and Dean $(1977 \mathrm{~b})$ \\
T. plebeius & 58.88 & 0.08 & - & - & - & - & - & $90^{\circ}$ & Viégas $(1982)$ \\
T. plebeius & 51.73 & 0.25 & - & - & - & - & - & $90^{\circ} 40^{\prime}$ & Viégas $(1982)$ \\
T. dombeii & 88.5 & 0.23 & 0.84 & - & 3.26 & - & - & $36^{\circ} 00^{\prime}$ & Urban $(1996)^{\prime}$ \\
T. plebeius & - & - & - & - & - & W-Spr & S & $37^{\circ} 40^{\prime}$ Clédon et al. (2004) \\
T. plebeius & 67.01 & 1.73 & 3.12 & $1.58-2.25$ & 3.89 & - & - & $23^{\circ} 43^{\prime}$ Abrahão et al. (2010) \\
T. plebeius & - & - & - & - & - & W-Spr & W-Spr & $14^{\circ} 16^{\prime}$ Ceuta and Boehs (2012) \\
T. plebeius & 74.14 & 0.52 & 2.16 & 2.58 & 3.46 & W-Spr & S & $23^{\circ} 37^{\prime}$ Current study \\
\hline
\end{tabular}

$L_{\infty}$ asymptotic length, $K$ curvature parameter, $Z$ mortality rate, $\phi^{\prime}$ standard growth index, $W-S p r$ winter-spring, $S$ summer

(0.14 year $^{-1}$ at $54^{\circ} \mathrm{S}$, Lomovasky et al. 2002). Another factor that may be influencing the mortality rate of the $T$. plebeius population is the predation pressure over this species. The positive values of the $\Delta_{Z / K}$ parameter confirm the high level of predation (by natural predators or by anthropic action) at Camaroeiro Beach and highlight the importance of research surveys to assess population trends and stock assessments for T. plebeius in this area.

The relative amplitude of seasonal oscillations in growth rate, $C=0.47$, indicated a moderately seasonal variation in growth. Growth was slowest at the winter point (WP) of 0.94 year units, equivalent to the summer $(\sim$ mid-December). Histological analyses showed that during the 7 months analyzed in this study, the more intense period of gametogenesis in T. plebeius at Camaroeiro Beach occurred in summer months (January-March) right after the WP (Fig. 7). In this sense, the recorded WP may be related to a higher reproductive investment, with energy being transferred from somatic growth to the production of gametes.

Despite the reduced number of studies that analyzed the reproductive biology of $T$. plebeius, different reproduction patterns seem to occur for this species over the range of its distribution. A continuous gametogenic cycle, with both females and males undergoing gametogenesis and spawning throughout the year, was recorded in a tropical estuary in northeastern Brazil ( $14^{\circ} \mathrm{S}$, Ceuta and Boehs 2012), whereas two spawning peaks, one in summer (between December and January) and the other in winter (June and July), were evidenced in northern Argentina $\left(37^{\circ} \mathrm{S}\right.$, Clédon et al. 2004). At Camaroeiro Beach, a spawning peak was recorded in summer (between November 2006 and January 2007). After spawning, gonad recovery was immediate and most individuals were at maximum maturation and spawning in late autumn (May 2007). These results suggest a biannual gametogenic cycle for $T$. plebeius at Camaroeiro, a similar pattern to that recorded in northern Argentina (Clédon et al. 2004) and also observed in several populations of bivalves from subtropical and temperate areas, such as Donax trunculus (Tirado \& Salas 1998, Gaspar et al. 1999), Protothaca antiqua (Borzone, 1989), and the razor clams T. dombeii (Avellanal et al. 2002) and Ensis mancha (Avellanal et al. 2002, Barón et al. 2004). However, as we have only seven months of histological analyses for the individuals from Camaroeiro, further studies with a greater period of sample are necessary to better elucidate the reproductive pattern of $T$. plebeius in this area.

The monthly variation in the mean oocyte area of $T$. plebeius corroborated our qualitative histological analyses, and a lower mean oocyte area was related to the gametogenesis stage due to the high quantity of developing (small) gametes. Conversely, when the ripe stage occurred, the mean oocyte area showed high values due to the presence of mature gametes. The equal sex ratio observed in this study is in agreement with observations by Clédon et al. (2004) and Ceuta and Boehs (2012) in other occurrence areas.

Although we did not analyze the annual somatic production $(P)$, annual mean biomass $(B)$, and turnover rate $(P / B)$, several reasonable extrapolations about these parameters can be developed. The low recruitment rate observed at Camaroeiro Beach generates a size structure composed mainly of adult clams, which have a high mean body mass $(B)$ but a low growth rate $(K)$. As smaller individuals are responsible for a considerable percentage of the population production (Robertson 1979; Urban and Campos 1994), the turnover rate $(P / B)$ is strongly influenced by the size structure of the population (Benke and Huryn 2006); therefore, the $P / B$ ratio should be low in populations composed of larger individuals, as in the population at Camaroeiro. This fact leads to a low restoration of the population of $T$. plebeius, and together with the low recruitment and high mortality rate $(Z)$, could be an indication that the population of T. plebeius at Camaroeiro Beach is endangered.

This study provides baseline knowledge on $T$. plebeius that we expect to be useful for avoiding negative impacts to this species. Although this information is relevant to 
support fishing activity, it is only a snapshot of $T$. plebeius population biology, and further studies on the range of this species distribution are required to better understand its population dynamics. It is necessary to improve our knowledge on the population biology of exploited species to develop correct management plans to prevent further uncontrolled exploitation and/or to achieve a more sustainable development of invertebrate fisheries (Botsford et al. 1997; Castilla and Defeo 2001; Anderson et al. 2011).

Acknowledgments We would like to thank R.F. Daolio, C.C. Taffarello, and F.S. MacCord, who contributed to the fieldwork. This work was supported by the Fundação de Apoio à Pesquisa do Estado de São Paulo-FAPESP (06/53561-6), Coordenação de Aperfeiçoamento de Pessoal de Nível Superior (CAPES), Conselho Nacional de Desenvolvimento Científico e Tecnológico (CNPq), FAEPEX/UNICAMP, and Centro de Biologia Marinha da USP (CEBIMar).

\section{References}

Abrahão JR, Amaral ACZ (1999) Tamanho, densidade e distribuição de Tagelus plebeius (Veneroidea: Psammobiidae) em uma praia arenosa, São Paulo, Brasil. Iheringia Sér Zool 87:181-190

Abrahão JR, Cardoso RS, Yokoyama LQ, Amaral ACZ (2010) Population biology and secondary production of the stout razor clam Tagelus plebeius (Bivalvia, Solecurtidae) on a sandflat in southeastern Brazil. Zoologia 27(1):54-64

Amaral ACZ, Denadai MR (2011) Caracterização de praias arenosas. In: Amaral ACZ, Nallin SAH (eds) Biodiversidade e ecossistemas bentônicos marinhos do Litoral Norte de São PauloSudeste do Brazil. Unicamp/IB, Campinas, SP, pp 354-369

Anderson SC, Flemming JM, Watson R, Lotze HK (2011) Rapid global expansion of invertebrate fisheries: trends, drivers, and ecosystem effects. PLoS One 6(3):e14735

Avellanal MHE, Jaramillo E, Clasing E, Quijón P, Contreras H (2002) Reproductive cycle of the bivalves Ensis mancha (Molina, 1782) (Solenidae), Tagelus dombeii (Lammarck, 1818) (Solecurtidae) and Mulina edulis (King, 1831) (Mactridae) in Southern Chile. Veliger 45:33-44

Barón PJ, Real LE, Ciocco NF, Ré ME (2004) Morphometry, growth, reproduction of an Atlantic population of the razor clam Ensis macha (Molina, 1782). Sci Mar 68(2):211-217

Bayne BL, Worrall CM (1980) Growth and production of mussels Mytilus edulis from two populations. Mar Ecol Prog Ser 3:317-328

Beasley CR, Fernandes CM, Gomes CP, Brito BA, Santos SML, Tagliaro CH (2005) Molluscan diversity and abundance among costal habitats of Northern Brazil. Ecotropica 11:9-20

Benke AC, Huryn AD (2006) Secondary production of macroinvertebrates. In: Hauer FR, Lamberti GA (eds) Methods in stream ecology, 2nd edn. Academic Press, Burlington, pp 691-710

Borzone CC (1989) El ciclo gonadal de Venus antigua King \& Broderip, 1935 (Veneridae: Bivlvia) en el golfo San José. Physis 47:61-72

Botsford LW, Castilla JC, Peterson CH (1997) The management of fisheries and marine ecosystems. Science 277:509-515

Brey T, Gage J (1997) Interactions of growth and mortality in benthic invertebrate populations: empirical evidence for a mortalitygrowth continuum. Arch Fish Mar Res 45:45-49

Calderon-Aguilera LE, Aragón-Noriega EA, Reyes-Bonilla H, Paniagua-Chavez CG, Romo-Curiel AE, Moreno-Rivera VM (2010) Reproduction of the Cortes geoduck Panopea globosa
(Bivalvia: Hiatellidae) and Its relationship with temperature and ocean productivity. J Shellfish Res 29(1):135-141

Castilla JC, Defeo O (2001) Latin American benthic shellfisheries: emphasis on co-management and experimental practices. Rev Fish Biol Fish 11:1-30

Ceuta L, Boehs G (2012) Reproductive cycle of Tagelus plebeius (Mollusca: Bivalvia) in the estuary of the Cachoeira River, Ilhéus, Bahia Brazil. Braz J Biol 72(3):569-576

Chatzinikolaou E, Richardson CA (2008) Population dynamics and growth of Nassarius reticulatus (Gastropoda: Nassariidae) in Rhosneigr (Anglesey, UK). Mar Biol 153:605-619

Clédon M, Peralta-Brichtova AC, Gutiérrez JL, Penchaszadeh PE (2004) Reproductive cycle of the razor clam, Tagelus plebeius (Lightfoot, 1786), in the Mar Chiquita Coastal Lagoon, Argentina. J Shellfish Res 23:443-446

Corte GN, Yokoyama LQ, Amaral ACZ (2013) An attempt to extend the habitat harshness hypothesis to tidal flats: a case study of Anomalocardia brasiliana (Bivalvia: Veneridae) reproductive biology. Estuar Coast Shelfish Sci. doi:10.1016/j.ecss.2013.12. 007

Dayton PK, Thrush SF, Agardy MT, Hoffman RJ (1995) Environmental effects of marine fishing. Aquat Conserv Mar Freshw Ecosyst 5:205-232

Defeo O (2003) Marine invertebrate fisheries in sandy beaches: an overview. J Coast Res 35:56-65

Defeo O, Cardoso RS (2002) Macroecology of population dynamics and life history traits of the mole crab Emerita brasiliensis in Atlantic sandy beaches of South America. Mar Ecol Prog Ser 239:169-179

Defeo O, Cardoso RS (2004) Latitudinal patterns in abundance and life-history traits of the mole crab Emerita brasiliensis on South American sandy beaches. Divers Distrib 10:89-98

Defeo O, Martínez G (2003) The habitat harshness hypothesis revisited: life history of the isopod Excirolana brasiliensis in sandy beaches with contrasting morphodynamics. J Mar Biol Assoc UK 83:331-340

Defeo O, Arreguín-Sánchez F, Sánchez J (1992) Growth study of the yellow clam Mesodesma mactroides: a comparative analysis of three length-based methods. Sci Mar 56:53-59

Defeo O, Gomez J, Lercari D (2001) Testing the swash exclusion hypothesis in sandy beach populations: the mole crab Emerita brasiliensis in Uruguay. Mar Ecol Prog Ser 212:159-170

Fagundes L, Gelli VC, Otani MN, Vicente MCM, Fredo CE (2004) Perfil sócio-econômico dos mitilicultores do Litoral Paulista. Inf Paul 34(5):47-59

Fahy E, Gafnney J (2001) Growth statistics of an exploited razor clam (Ensis siliqua) bed at Gormanstown, Co Meath, Ireland. Hydrobiologia 465:139-151

Farias MF, Rocha-Barreira CA (2012) Aspectos populacionais de Tagelus plebeius (Mollusca: Bivalvia: Solecurtidae) no estuário do Rio Ceará, Nordeste do Brasil. Arq Ciênc Mar 45(2):32-39

Farinaccio A, Tessler MG (2006) Dinâmica de sedimentação na Ponta do Camaroeiro, porção Norte da Enseada de Caraguatatuba, SP. Geociências 23(3):331-344

Ferns PN, Rostron DM, Siman HY (2000) Effects of mechanical cockle harvesting on intertidal communities. J Appl Ecol 37:464-474

García-Berthou E, Carmona-Catot G, Merciai R, Ogle DH (2012) A technical note on seasonal growth models. Rev Fish Biol Fisher 22:635-640

Gaspar MB, Monteiro CC (1998) Reproductive cycles of the razor clam Ensis siliqua and the clam Venus striatula off vilamoura, southern Portugal. J Mar Biol Assoc UK 78:1247-1258

Gayanilo FC, Sparre P, Pauly D (2005) FAO-ICLARM stock assessment tools II: user's guide. Worldfish Center, Penang 
Gómez J, Defeo O (1999) Life history of the sandhopper Pseudorchestoidea brasiliensis (Amphipoda) in sandy beaches with contrasting morphodynamics. Mar Ecol Prog Ser 182:209-220

Grant J, Daborn G (1994) Effects of bioturbation on sediment transport in an intertidal mudflat. Neth J Sea Res 32:63-73

Gutiérrez JL, Iribarne OO (2003) Spatial variation in the body mass of the stout razor clam, Tagelus plebeius: does the density of burrowing crabs, Chasmagnathus granulata, matter? J Shellfish Res 22(1):69-73

Gutiérrez JL, Palomo MG, Iribarne OO (2004) Environmental heterogeneity and species responses to fishing disturbance: are the effects of clam harvesting spatially consistent? Fish Res 67:55-70

Henderson SM, Richardson CA (1994) A comparison of the age, growth rate and burrowing behavior of the razor clams, Ensis siliqua and E. ensis. J Mar Biol Assoc UK 74:939-954

Herrmann M, Carstensen D, Fischer S, Laudien J, Penchaszadeh P, Arntz WE (2009) Population structure, growth, and production of the wedge clam Donax hanleyanus (Bivalvia: Donacidae) from Northern Argentinean beaches. J Shellfish Res 28(3):511-526

Herrmann M, Alfaya JEF, Lepore ML, Penchaszadeh PE, Arntz WE (2011) Population structure, growth, and production of the yellow clam Mesodesma mactroides (Bivalvia: Mesodesmatidae) from a high-energy, temperate beach in northern Argentina. Helgol Mar Res 65:285-297

Hines AH, Haddon AM, Weichert L (1990) Guilda structure and foraging impact of blue crabs and epibenthic fish in a subestuary of Chesapeake Bay. Mar Ecol Prog Ser 67:105-126

Holland AF, Dean JM (1977a) The biology of the Stout Razor Clam Tagelus plebeius: I. animal-sediment relationships, feeding mechanism, and community biology. Chesap Sci 18:58-66

Holland AF, Dean JM (1977b) The Biology of the Stout Razor Clam Tagelus plebeius: II. some aspects of the population dynamic. Chesap Sci 18:188-196

Humanson GL (1979) Animal tissue technique. Freeman, San Francisco

Lardies MA, Clasing E, Navarro JM, Stead RA (2001) Effects of environmental variables on burial depth of two infaunal bivalves inhabiting a tidal flat in southern Chile. J Mar Biol Assoc UK $81: 809-816$

Lin J, Hines A (1994) Effects of suspended food availability on the feeding mode and burial depth of the Baltic clam Macoma balthica. Oikos 69:28-36
Lomovasky BJ, Brey T, Morriconi E, Calvo J (2002) Growth and production of the venerid bivalve Eurhomalea exalbida in the Beagle Channel, Tierra del Fuego. J Sea Res 48:209-216

Lomovasky JB, Casariego AM, Brey T, Iribarne O (2006) The effect of the SW Atlantic burrowing crab Chasmagnathus granulatus on the intertidal razor clam Tagelus plebeius. J Exp Mar Biol Ecol 337:19-29

Metaxatos A (2004) Population dynamics of the venerid bivalve Callista chione L. in a coastal area of the eastern Mediterranean. J Sea Res 52(4):293-305

Morsan EM, Kroeck MA (2005) Reproductive cycle of purple clam, Amiantis purpurata (Bivalvia: Veneridae) in northern Patagonia (Argentina). J Mar Biol Assoc UK 85:367-373

Pauly D (1984a) Length-converted catch curves: a powerful tool for fisheries research in the tropics (Part II). Fishbyte 2(1):17-19

Pauly D (1984b) Length-converted catch curves: a powerful tool for fisheries research in the tropics (Part III). Fishbyte 2(3):8-10

Pauly D, Munro JL (1984) Once more on the comparison of growth in fish and invertebrates. Fishbyte 2:21

Petracco M, Veloso VG, Cardoso RS (2003) Population dynamics and secondary production of Emerita brasiliensis (Crustacea: Hippidae) at Prainha Beach. Brazil. Mar Ecol 24(3):231-245

Rios E (1994) Sea shells of Brazil. da FURG, Rio Grande

Robertson AI (1979) The relationship between annual production: biomass ratio and lifespan for marine macrobenthos. Oecologia 38:193-202

Urban HJ (1996) Population dynamics of the bivalves Venus antigua, Tagelus dombeii, and Ensis macha from Chile at $36^{\circ} \mathrm{S}$. J Shellfish Res 15(3):719-727

Urban HJ, Campos B (1994) Population dynamics of the bivalves Gari solida, Semele solida and Protothaca thaca from a small bay in Chile at $36^{\circ} \mathrm{S}$. Mar Ecol Prog Ser 115:93-102

Vásquez NN, Ituarte C, Navone CT, Cremonte F (2006) Parasites of the stout razor clam Tagelus plebeius (Psamobiidae) from the Southwestern Atlantic Ocean. J Shellfish Res 25(3):877-886

Verween A, Vincx M, Degraer S (2007) The effect of temperature and salinity on the survival of Mytilopsis leucophaeta larvae (Mollusca, Bivalvia): the search for environmental limits. J Exp Mar Biol Ecol 348:111-120

Viégas O (1982) Crescimento e produção de Tagelus plebeius (Solecurtidae: Bivalvia) no Canal do Calunga, Maceió, Alagoas. Atlântica 5(2):124-125 